\title{
PPARD wt Allele
}

National Cancer Institute

\section{Source}

National Cancer Institute. PPARD wt Allele. NCI Thesaurus. Code C96461.

Human PPARD wild-type allele is located in the vicinity of $6 \mathrm{p} 21.2$ and is approximately 85 $\mathrm{kb}$ in length. This allele, which encodes peroxisome proliferator-activated receptor delta protein, plays a role in embryo implantation, placental development, cholesterol homeostasis and transcriptional regulation. 